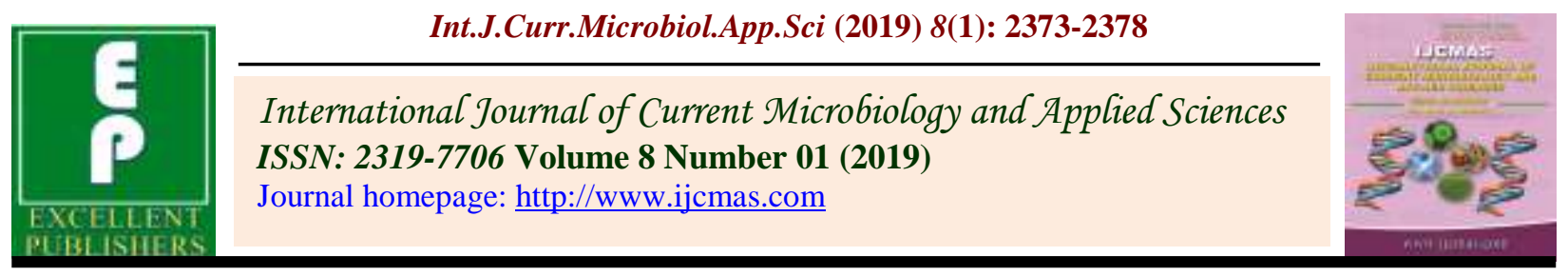

\title{
Profile Characteristics of Farmers in Adoption of BT Cotton
}

\author{
P. Pavan Kumar*, R.K. Dhorey and S.N. Singh \\ Department of Agricultural Extension, Narendra Dev University of Agriculture and \\ Technology Faizabad - 224229 (U.P), India \\ *Corresponding author
}

\begin{tabular}{|c|c|}
\hline & A B S T R A C T \\
\hline Keywords & \multirow{4}{*}{$\begin{array}{l}\text { The present investigation was carried out in Warangal district of Telangana. The study was } \\
\text { conducted in Warangal block of Warangal district (Telangana) selected purposively. A } \\
\text { total number of } 100 \text { respondents were selected through random sampling from } 5 \text { sample } \\
\text { villages on the basis of majority of Bt. Cotton growers. The structured schedule was } \\
\text { developed keeping in view the objectives \& variables under study. The respondents were } \\
\text { contacted personally for data collection. Salient findings of the study are, most of the } \\
\text { respondents }(63 \%) \text { were found in middle aged }(63 \%) \text {, had high school education }(29 \%) \text {, } \\
\text { other backward caste }(65 \%) \text {, Hindu religion }(100 \%) \text {, nuclear family }(73 \%,) \text { medium family } \\
\text { size }(50 \%) \text {, small farmers }(45 \%),(67 \%) \text { annual income }(150000-300000) \text {, respondents } \\
\text { Participation in one organization( }(70 \%) \text {, medium overall material possession( } 62 \%) \text {, } \\
\text { medium extension contact }(50.00 \%) \text {, medium economic motivation }(57 \%) \text {, medium } \\
\text { scientific orientation }(50 \%) \text {, medium risk orientation }(68 \%) \text {. }\end{array}$} \\
\hline $\begin{array}{l}\text { BT Cotton, } \\
\text { Gossypium } \\
\text { hirsutum L. }\end{array}$ & \\
\hline Article Info & \\
\hline $\begin{array}{l}\text { Accepted: } \\
\text { 15 December } 2018 \\
\text { Available Online: } \\
\text { 10 January } 2019\end{array}$ & \\
\hline
\end{tabular}

\section{Introduction}

Cotton (Gossypium hirsutum L.) referred to as the White Gold is one of the most important fiber and commercial crop playing a key role in economic, political and social affairs in our country as well as world. Cotton occupies a predominant place among cash crops touching the country's economy at several points by generating direct and indirect employment in the agricultural and industrial sectors.

Following a long history of cultivation of traditional varieties, hybrid cotton was introduced in India for the first time in 1970.This was in the state of Gujarat and by virtue of its high yield potential it became very popular. A large number of hybrids were released. However it was soon realized that the hybrids were highly susceptible to pest attack and damage. This became a severe problem especially from 1993-94 onwards, leading to frequent crop failures as well as fluctuating declining yields. Over 150 different insect pests species are reported to attack cotton at various stages of its growth causing sever reduction in yields, and reduction in massive pesticide use by farmers and high cost of cultivation. It is estimated that over $55 \%$ of the pesticides sold in the Country are used on cotton. The farmers have been highly dissatisfied and have been looking for cotton varieties that have pest resistant. It was at this juncture that the 
transgenic varieties with Bt. arrived on the world and then in the country.

Bt. cotton, the first genetically modified (GM) crop in India, was initially approved in India on March 26th 2002 for commercial cultivation in six states belonging to southern and central cotton cultivation zones of the country. The commercial cultivation of Bt. cotton in the world first began in 1996. The reason for the introduction of Bt. cotton was to counter attack the three types of bollworms, viz. American bollworm (Helicover paarmigera), pink bollworm (Pectinophora gossypiella) and spotted bollworms (Earias vitella) which used to cause substantial damage to the crop, resulting in low productivity. Therefore, Mahyco (Maharashtra Hybrid Seed Company), in collaboration with Monsanto, introduced Bt. cotton technology into India. Bt. cotton carries the CrylAcgene derived from the common soil bacterium Bacillus thuringiensis var. kurstaki, which results in the expression of the CrylAc protein that confers resistance to the bollworm complex (Barwal et. al.2004). Bt. cotton hybrids have exhibited excellent control of American Bollworm and reduced the use of insecticides. This has led to create ecofriendly environment without compromising on profitable yield (Manikin et. al.2008). In addition to reducing production cost and increasing profit, Bt. cotton has lowered farming risk and improved farmer's perspective in cultivating cotton crop.

\section{Materials and Methods}

Warangal district of Telangana will be purposively selected for higher production of Bt. cotton, Warangal is the second largest Bt. Cotton producer in Telangana state with the area of more than 2 lakh hectares of land, and locale for present investigation because the researcher is well acquainted with the locality and culture. District Warangal comprised of 9 Community development blocks. Out of these 9 blocks, the Warangal block will be selected purposively for the study because of the Warangal block is second largest producer of Bt. Cotton in district and its easy accessibility and familiarity of researcher with the local language, socio economic and cultural conditions.

An exhaustive list of village of Warangal block will be prepared and 5 villages will be selected randomly. Moreover, list of farm families from each of the selected village will be prepared and 20 respondents from each of the selected village will be identified through random sampling technique. Thus a total of 100 rural farmers constitutes the sample size for the purpose of further investigation. A knowledge test was developed. Data was collected using interview schedule developed for the study. Based on obtained scores the respondents were grouped into low, medium and high knowledge categories according to equal interval method. The collected data was analysed using appropriate statistical tools like frequency and percentage, class interval, arithmetic mean $(X)$, standard deviation and co- efficient of correlation.

\section{Results and Discussion}

\section{Age}

From table 1 found that, most of $(63 \%)$ the respondents were belonged to middle age followed by old (19\%) and young (18\%) age categories.

The probable reason might be that young farmers have been engaged in activities others than agriculture and old farmers may be due to their traditional outlook and also being less energetic are reluctant to practice new technologies. Hence majority of Bt. Cotton farmers found to be middle aged farmers. 


\section{Education}

From table 1 found that most of the farmers were educated up to high school level $(29 \%)$ followed by intermediate $(25 \%)$, graduate (14\%), primary school (12\%), and 20 per cent of farmers were found to be illiterate.

The probable reason for this might be that, even today there is no access for villagers to college education at village level. They have to go to Mandal headquarters if they want peruse college education. Hence majority of the farmers got educated only up to high school education.

\section{Caste}

From table 1 found that most of the farmers were $(65 \%)$ other backward caste followed by scheduled cast $(23 \%)$ and general caste $(12 \%)$ respectively.

\section{Type of family}

From table 1 found that most $(73 \%)$ of the farmers were nuclear/single family and $(27 \%)$ of the farmers were joint family.

\section{Size of family}

From table 1 found that most $(50 \%)$ of the farmers were medium size family followed by small $(41 \%)$ and large $(9 \%)$.

\section{Farm Size}

From table 1 found that, most (45\%) of the farmers were small farmers followed by medium (37\%), and marginal (18\%) farmers.

The reason for this kind of result might be the fragmentation of land holdings from generation to generation led to most of big famers turning to small, medium and marginal farmers.
The majority of farmers are, small, medium, marginal, the extension agencies have to take care while introducing technologies, for sustainable production in available land.

\section{Annual income}

From table 1 it was found that, most (67\%) of the farmers were medium income level followed by low (19\%) and high (14\%) income level.

The reason for this kind of result was most of the farmers getting low yields, more attack of pest and disease and low market price.

\section{Social participation}

From table 1 found that, most $(67 \%)$ of the farmers were participate in one organization followed by $(27 \%)$ participate in two organization, $(2 \%)$ of the farmers not participating in any organization and $(1 \%)$ of respondents participated in more than two organizations.

The reason for this kind of result was most of the farmers were low education qualifications and less aware about social relationships.

\section{Material possession}

From table 1 found that majority (62\%) of the respondents had medium over all material possession status followed by low $(24.00 \%)$ and high (14.00\%) over material possession status

It could be furnished that majority of the respondents had medium over all material possession status. This trend indicates that respondents have greater scope to farm mechanization. And every farmers cannot afford to have all adequate farm machinery at his disposal and it is not economical in terms of its maintenance and use. This might be the 
probable reason for medium over all material possession status.

\section{Extension contact}

From table 1 found that majority $(50.00 \%)$ of the respondents were found to possess medium extension contacts, followed by low $(46 \%)$ and high (3\%) extension contacts.

Majority of the respondents had medium to low extension contacts with the government, non-government and private extension agencies. This might be due to the fact that as majority of respondents were small and medium farmers with low farming experience and primary school education. They may not be having frequent contact with officials due to fear and inhibition. Inadequate staff may be another reason for this result.

Hence recruitment of adequate staff and providing quality extension services will improve the situation. Further, instead of expecting farmers to visit the extension workers/ research worker office, these extension and research functionaries should go to villages very frequently and organize extension activities in the villages itself, which serves a dual purpose of increasing knowledge among the farmers and getting feedback from farmers.

\section{Economic motivation}

From table 1 found that majority (57\%) of the respondents were found medium economic motivation, followed by low (23\%) and high (20\%) economic motivation.

Majority of the respondents in the present study had medium economic motivation.

\section{Scientific orientation}

From table 1 found that majority (50\%) of the respondents were found medium scientific orientation, followed by low (28\%) and high (22\%) scientific orientation.

Majority of the respondents in the present study had medium scientific orientation. Scientific orientation involves an element of risk; most of the small farmers cannot afford taking risk by practicing innovations.

Table.1 Distribution of respondents according to their profile characters. $\quad \mathrm{N}=100$

\begin{tabular}{|l|l|c|c|}
\hline \multicolumn{2}{|l|}{} & \multicolumn{2}{|c|}{$\begin{array}{c}\mathbf{N} \\
\mathbf{1 0 0}\end{array}$} \\
\hline S. No. & Category & Frequency & Percentage \\
\hline Age & & & \\
\hline $\mathbf{1}$ & Young age (up to 36) & 18 & 18.00 \\
\hline $\mathbf{2}$ & Middle age (37-47) & 63 & 63.00 \\
\hline $\mathbf{3}$ & Old age (48 and above years) & 19 & 19.00 \\
\hline Education & & & \\
\hline $\mathbf{1}$ & Illiterate & 20 & 20.00 \\
\hline $\mathbf{2}$ & Literate & 80 & 80.00 \\
\hline & Total & 100 & 100 \\
\hline $\mathbf{2}$ & Primary School & 12 & 12.00 \\
\hline $\mathbf{3}$ & High school & 29 & 29.00 \\
\hline $\mathbf{4}$ & Intermediate & 25 & 25.00 \\
\hline $\mathbf{5}$ & Under graduate & 14 & 14.00 \\
\hline Caste & & & \\
\hline
\end{tabular}




\begin{tabular}{|c|c|c|c|}
\hline 1 & General caste & 12 & 12.00 \\
\hline 2 & Other backward caste & 65 & 65.00 \\
\hline 3 & Scheduled caste & 23 & 23.00 \\
\hline \multicolumn{4}{|c|}{ Type of family } \\
\hline 1 & Nuclear/Single family & 73 & 73.00 \\
\hline 2 & Joint family & 27 & 27.00 \\
\hline \multicolumn{4}{|c|}{ Size of family } \\
\hline 1 & Small (up to 4) & 41 & 41.00 \\
\hline 2 & Medium (5-7) & 50 & 50.00 \\
\hline 3 & Large (8 and above) & 9 & 9.00 \\
\hline \multicolumn{4}{|c|}{ Farm size } \\
\hline 1 & Marginal (<1 ha) & 18 & 18.00 \\
\hline 2 & Small (1-2 ha) & 45 & 45.00 \\
\hline 3 & medium (2-4 ha) & 37 & 37.00 \\
\hline \multicolumn{4}{|c|}{ Annual income } \\
\hline & & & \\
\hline 1 & Low ) up to 135000 ) & 19 & 19.00 \\
\hline 2 & Medium (135000-300000) & 67 & 67.00 \\
\hline 3 & High (300000 and above) & 14 & 14.00 \\
\hline Social & \multicolumn{3}{|l|}{ participation } \\
\hline $\mathbf{1}$ & No participation & 2 & 2.00 \\
\hline 2 & Participation in one organization & 70 & 70.00 \\
\hline 3 & Participation in two organization & 27 & 27.00 \\
\hline 4 & Participation in more than two organization & 1 & 1.00 \\
\hline \multicolumn{4}{|c|}{ Material possession } \\
\hline & & & \\
\hline 1 & Low & 24 & 24.00 \\
\hline 2 & Medium & 62 & 62.00 \\
\hline 3 & High & 14 & 14.00 \\
\hline \multicolumn{4}{|c|}{ Extension contact } \\
\hline & & & \\
\hline 1 & Low & 46 & 46.00 \\
\hline 2 & Medium & 50 & 50.00 \\
\hline 3 & High & 3 & 3.00 \\
\hline \multicolumn{4}{|c|}{ Economic motivation } \\
\hline 1 & Low & 23 & 2300 \\
\hline 2 & Medium & 57 & 57.00 \\
\hline 3 & High & 20 & 20.00 \\
\hline \multicolumn{4}{|c|}{ Scientific orientation } \\
\hline 1 & Low & 28 & 28.00 \\
\hline 2 & Medium & 50 & 50.00 \\
\hline 3 & High & 22 & 22.00 \\
\hline \multicolumn{4}{|c|}{ Risk orientation } \\
\hline 1 & Low & 17 & 17.00 \\
\hline 2 & Medium & 68 & 68.00 \\
\hline 3 & High & 15 & 15.00 \\
\hline
\end{tabular}

\section{Risk orientation}


From table 1 found that majority $(68.00 \%)$ of the respondents had medium risk orientation followed by low (17\%) and high (15\%) risk orientation.

The possible reason for this result might be that majority of respondents had education up to high school and belonged to functionally literate category with medium to low extension contact. Another important reason might be the mindset, and lack of awareness of the respondents.

Extension workers should maintain closer rapport with farmers to make them understand the Bt. Cotton cultivation practices. They should also help them to overcome the problems in adoption and suggest alternatives and induce confidence. As a result, unnecessary fears and confusion prevailing in the farmers can be eliminated and they can be made to easily adopt the technology.

\section{References}

Gangadhar, J. (2009). Marketing behavior of cotton farmers in Warangal district of Andhra Pradesh. M.Sc. (Ag.) Thesis. Acharya N G Ranga Agricultural University, Hyderabad.

Joshi, P. L. (2004). Extent of knowledge and adoption of cotton growers about modern practices of cotton in Bhal area. M.Sc. $(A g)$. GAU, Anand Campus, Anand.

Mukunda Rao, B. (2011). An analysis study on Bt. cotton cultivation in Andhra Pradesh. Ph. D Thesis. Acharya N.G. Ranga Agricultural University, Hyderabad, India.

Prasanth. (2011). A study on adoption of organic farming in cotton in Karimnagar district of Andhra Pradesh. M. Sc. (Ag) thesis submitted to Acharya N G Ranga Agricultural University, Hyderabad.

Pradeep, K.P.B. (2011). Interactive multimedia module development on Integrated Pest Management in cotton and its effectiveness. Ph.D. Thesis Acharya N.G. Ranga Agricultural University, Hyderabad, India.

Sajith, G. K. (2004). Adoption of recommended package of practices by the coconut farmers of Mahe region of Union Territory of Pondicherry. M.Sc. (Ag) Thesis Acharya N G Ranga Agricultural University, Hyderabad.

Sarda, M. K and Gill, S. S. (2005). Training needs of input dealers on pesticide application on cotton crop in Punjab. MANAGE Extension Research Review. Jan -July: 63-64.

Sivanarayana, G., Ramadevi, M.and Venkataramaiah, P. (2008). Awareness and adoption of cotton (Gossipium hirsutum L.) Integrated Pest Management practices by the farmers of Warangal district in Andhra Pradesh. J. of Research, ANGRAU.36: 33-40.

Sunit, B.; Rajmane; Milind, C.; Ahire and Ravindra. (2009). Mass media preferences of cotton growers. $J$. of Communication Studies. 27: 32-38.

Thangaraja, K.; Karthikeyan, C.; Ashokhan, M. and Rajasekharan, R. (2008). Socioeconomic characteristics of the dry land farmers in Dindgul district of Tamil Nadu. Madras Agricultural J. 95: 120128.

Veeraiah, R..; Prakash Atkare and Rao, D. V. (2005). Success stories of cotton farmers to study the adoption behavior on Integrated Pest Management of cotton in Nalgonda District. Agricultural Ext. Review. 17 (5): 22-25.

\section{How to cite this article:}

Pavan kumar, P., R.K. Dhorey and Singh, S.N. 2019. Profile Characteristics of Farmers in Adoption of BT.Cotton. Int.J.Curr.Microbiol.App.Sci. 8 (01): 2373-2378. doi: https://doi.org/10.20546/ijcmas.2019.801.249 